\begin{tabular}{|c|c|}
\hline Title & Doping effect of $\mathrm{Nb}$ species on hydrogen desorption properties of AIH3 \\
\hline Author(s) & $\begin{array}{l}\text { Nakagawa, Y uki; Lee, Chung-Hyun; Matsui, Kouki; Kousaka, Kohei; I sobe, Shigehito; Hashimoto, Naoy uki; } \\
\text { Y amaguchi, Shotaro; Miy aoka, Hiroki; Ichikawa, Takay uki; Kojima, Y oshitsugu }\end{array}$ \\
\hline Citation & $\begin{array}{l}\text { Journal of alloys and compounds, } 734,55-59 \\
\text { https://doi.org/10.1016/.jall lcom.2017.10.273 }\end{array}$ \\
\hline Issue Date & $2018-02-15$ \\
\hline Doc URL & http:/hdl .handle.net/2115/76747 \\
\hline Rights & $\begin{array}{l}\text { () 2018. This manuscript version is made available under the CC-BY-NC-ND } 4.0 \text { license } \\
\text { http://creativecommons.org/icenses/by-nc-nd/4.0/ }\end{array}$ \\
\hline Rights(URL) & http://creativecommons.org/icenses/by-nc-nd/4.0/ \\
\hline Type & article (author version) \\
\hline File Information & 3rd draft.pdf \\
\hline
\end{tabular}

Instructions for use 


\title{
Doping effect of Nb species on hydrogen desorption properties of $\mathrm{AlH}_{3}$
}

Yuki Nakagawa ${ }^{a^{*}}$, Chung-Hyun Lee ${ }^{\mathrm{a}}$, Kouki Matsui ${ }^{\mathrm{a}}$, Kohei Kousaka ${ }^{\mathrm{a}}$, Shigehito Isobe ${ }^{\mathrm{a}}$, Naoyuki Hashimoto ${ }^{\mathrm{a}}$, Shotaro Yamaguchi ${ }^{\mathrm{b}}$, Hiroki Miyaoka ${ }^{\mathrm{c}}$, Takayuki Ichikawa ${ }^{\mathrm{d}}$, Yoshitsugu Kojima $^{\mathrm{c}}$

${ }^{a}$ Graduate School of Engineering, Hokkaido University, N-13, W-8, Sapporo, 060-8278, Japan

${ }^{\mathrm{b}}$ Graduate School of Advanced Sciences of Matter, and ${ }^{\mathrm{c}}$ Natural Science Center for Basic Research and Development, Hiroshima University, 1-3-1 Kagamiyama, Higashi-Hiroshima, 7398530, Japan

d Graduate School of Engineering, Hiroshima University, 1-4-1 Kagamiyama, HigashiHiroshima, 739-8527, Japan.

\begin{abstract}
:
Hydrogen desorption properties of $\alpha-\mathrm{AlH}_{3}$ doped with $\mathrm{Nb}$ species $\left(\mathrm{Nb}, \mathrm{Nb}_{2} \mathrm{O}_{5}\right.$ and $\left.\mathrm{NbF}_{5}\right)$ were investigated. Doping $\mathrm{Nb}$ species improved the desorption properties of $\mathrm{AlH}_{3}$. In particular, 1 mol\% $\mathrm{NbF}_{5}$-doped $\mathrm{AlH}_{3}$ showed the lowest onset desorption temperature at $60{ }^{\circ} \mathrm{C}$. Compared with $\mathrm{Nb}$ - or $\mathrm{Nb}_{2} \mathrm{O}_{5}$-doped $\mathrm{AlH}_{3}$, the fine distribution of dopant was successfully achieved in $\mathrm{NbF}_{5}$-doped $\mathrm{AlH}_{3}$. The apparent activation energy for hydrogen desorption of $\mathrm{AlH}_{3}$ was slightly decreased with the dopant of $\mathrm{NbF}_{5}$. The improvement of desorption properties might be due to the finely dispersed $\mathrm{Nb}$ and/or $\mathrm{AlF}_{3}$, which are formed by the reaction between $\mathrm{NbF}_{5}$ and $\mathrm{AlH}_{3}$ (surface $\mathrm{Al}_{2} \mathrm{O}_{3}$ ).
\end{abstract}

Keywords: Hydrogen storage; Aluminum hydride, Niobium Fluoride, Niobium oxide, Catalytic effect 


\section{Introduction}

Aluminum hydride $\left(\mathrm{AlH}_{3}\right)$ is an ideal off-board hydrogen storage material because of its high hydrogen capacities (10.1 mass $\%$ and $\left.149 \mathrm{~g} \mathrm{H}_{2} / \mathrm{L}\right)$ and low desorption temperature $\left(<100{ }^{\circ} \mathrm{C}\right)$ [1]. However, its desorption kinetics is not enough to meet the targets for practical applications [2]. Although $\mathrm{AlH}_{3}$ is thermodynamically metastable at room temperature, it has been suggested that the surface $\mathrm{Al}_{2} \mathrm{O}_{3}$ film on $\mathrm{AlH}_{3}$ particle would inhibit the spontaneous decomposition at room temperature [3]. Ball-milling can enhance the desorption kinetics of $\mathrm{AlH}_{3}$, likely due to an increase of oxide free surfaces on $\mathrm{AlH}_{3}$ particles [3,4]. However, the mechanistic study showed that the real reason for the enhancement would be the small amount of desorption during ballmilling $[5,6]$. The formation of metallic Al particles on the hydride surface would serve as channels for the enhanced desorption and reduce the incubation period [5,6]. In addition, doping additives is one of the common strategies to enhance the kinetics of $\mathrm{AlH}_{3}$. For instance, the enhanced desorption properties have been reported for the reactive hydride composites between $\mathrm{AlH}_{3}$ and other compounds $\left(\mathrm{MgH}_{2}\right.$ [7,8], $\mathrm{LiBH}_{4}$ [9], $\mathrm{MgCl}_{2}$ [10] etc.). Also, Ti is a well-known and effective catalyst for $\mathrm{AlH}_{3}$. The measurable enhancement of kinetics was observed by doping $\mathrm{TiCl}_{3}$ with just a few ppm levels in solution during the $\mathrm{AlH}_{3}$ synthesis [6].

Nb-based additives have been considered as effective dopants to improve hydrogen sorption reactions of hydrogen storage materials. For instance, $\mathrm{Nb}_{2} \mathrm{O}_{5}$ is a well-known catalyst for hydrogen absorption and desorption reactions of $\mathrm{MgH}_{2}$ [11-14]. The composite, $\mathrm{MgH}_{2}$ and 1 mol\% $\mathrm{Nb}_{2} \mathrm{O}_{5}$ milled for $20 \mathrm{~h}$, was able to absorb -4.5 mass\% of hydrogen within $15 \mathrm{~s}$ at room temperature under lower pressure than 1.0 MPa and desorb -6.0 mass\% of hydrogen at $160{ }^{\circ} \mathrm{C}$ [12]. Also, $\mathrm{NbF}_{5}$ is also an effective dopant for various kinds of hydrogen storage materials, such as $\mathrm{MgH}_{2}$ [15,16], alanate [17,18] and borohydride [19] system. The composite, $\mathrm{MgH}_{2}$ and 2 mol\% $\mathrm{NbF}_{5}$ milled for $5 \mathrm{~h}$, was able to absorb -5.0 mass\% of hydrogen in $12 \mathrm{~s}$ and desorb -4.4 
mass\% of hydrogen in 10 min at $300{ }^{\circ} \mathrm{C}$ [15]. Hydrogen desorption properties of $\mathrm{MgH}_{2}-\mathrm{AlH}_{3}$ nanocomposites were investigated in the previous study, where the addition of just $1 \mathrm{~mol} \% \mathrm{NbF}_{5}$ remarkably destabilized $\gamma-\mathrm{AlH}_{3}$ in the composite and led to its decomposition at room temperature [8]. Other fluorides, such as $\mathrm{CeF}_{4}$ [20] and $\mathrm{TiF}_{4}$ [21], were also effective additives to enhance the kinetics of $\mathrm{MgH}_{2}$.

Thus, the addition of Nb-based additives showed the improvements of de/absorption properties of hydrogen storage materials. However, the effect of Nb-based additives on $\alpha-\mathrm{AlH}_{3}$ (the most stable phase of $\mathrm{AlH}_{3}$ ) has not been reported. In the present study, $\mathrm{Nb}, \mathrm{Nb}_{2} \mathrm{O}_{5}$, and $\mathrm{NbF}_{5}$ (hereinafter called "Nb species") were doped with $\alpha-\mathrm{AlH}_{3}$. Then, their hydrogen desorption properties and distribution states of $\mathrm{Nb}$ species were analyzed. In addition, the chemical bonding states of $\mathrm{Nb}$ and $\mathrm{F}$ were further investigated in the $\mathrm{NbF}_{5}$-doped $\mathrm{AlH}_{3}$ in order to clarify the reaction process.

\section{Experimental Section}

\section{Sample Synthesis}

Commercially available $\mathrm{Nb}$ (Kojundo Chemical Lab., 99.99 \%), $\mathrm{Nb}_{2} \mathrm{O}_{5}$ (Kojundo Chemical Lab., 99.99 \%), $\mathrm{NbF}_{5}$ (Sigma Aldrich, 98 \%) and $\mathrm{AlF}_{3}$ (Sigma Aldrich, $99.9 \%$ ) were used as-received for this research. $\mathrm{AlH}_{3}$ was prepared by the chemical reaction between $\mathrm{LiAlH}_{4}$ and $\mathrm{AlCl}_{3}$ in ether solution [22]. The samples were prepared by ball-milling $\mathrm{AlH}_{3}$ and $\mathrm{Nb}$ species using a planetary ball-mill apparatus (Fritsch Pulverisette 7) with $21 \mathrm{~g}$ of stainless balls and $100 \mathrm{mg}$ samples. The milling was performed under $0.1 \mathrm{MPa}$ Ar with $200 \mathrm{rpm}$ for $1 \mathrm{~h}$ with two cycles of 30/15 min operation/interval per each cycle. All material handlings were conducted under in a glovebox filled with purified Ar gas in order to avoid oxidation.

\section{Characterization}


Hydrogen desorption properties were examined by a thermogravimetry and differential thermal analysis equipment (TG-DTA, Bruker 2000SA) connected to a mass spectrometer (MS, ULVAC, BGM-102). The desorbed gases were carried from TG-DTA equipment to MS through a capillary by flowing high purity He gas as a carrier gas. The flow rate of He gas was set to 300

$\mathrm{mL} \mathrm{min}{ }^{-1}$. The samples were heated from room temperature to $200{ }^{\circ} \mathrm{C}$ with a heating rate of $5{ }^{\circ} \mathrm{C}$ $\min ^{-1}$. The crystalline phases of samples were analyzed by powder X-ray diffraction (XRD, PANalytical, X'Pert-Pro with Cu Ka radiation). The samples for XRD were placed on a glass plate in a glovebox and then covered with a polyimide sheet and sealed by grease in order to avoid the oxidation during the measurement. SEM-EDS measurements were performed to observe the distribution states of Nb species by using JIB-4600F/HKD, JEOL. The chemical bonding states of samples were studied by using X-ray Photoelectron Spectroscopy (XPS, Thermo Fisher Scientific, ESCALab 250Xi) with Al Ka radiation.

\section{Results and discussion \\ Doping effect of $\mathrm{Nb}$ species}

Fig. 1 shows the hydrogen desorption properties of as-synthesized, ball-milled, and Nb speciesdoped $\mathrm{AlH}_{3}$. As shown in Fig. 1(a) and (b), the hydrogen desorption temperature was reduced after ball-milling and doping with $\mathrm{Nb}$ species. The kinetic enhancement in the ball-milled $\mathrm{AlH}_{3}$ would originate from the formation of metallic $\mathrm{Al}$ particles on the hydride surface as shown in the "Introduction" part. In fact, the mass loss of ball-milled $\mathrm{AlH}_{3}(-9$ mass\%) was lower than that of as-synthesized $\mathrm{AlH}_{3}$ (-10 mass\%), suggesting the formation of metallic $\mathrm{Al}$ nuclei during ballmilling. It seemed that $\mathrm{Nb}$ - and $\mathrm{Nb}_{2} \mathrm{O}_{5}$-doped $\mathrm{AlH}_{3}$ showed the improvement of the desorption kinetics compared with ball-milled one. Among all the samples, $\mathrm{NbF}_{5}$-doped $\mathrm{AlH}_{3}$ showed the 

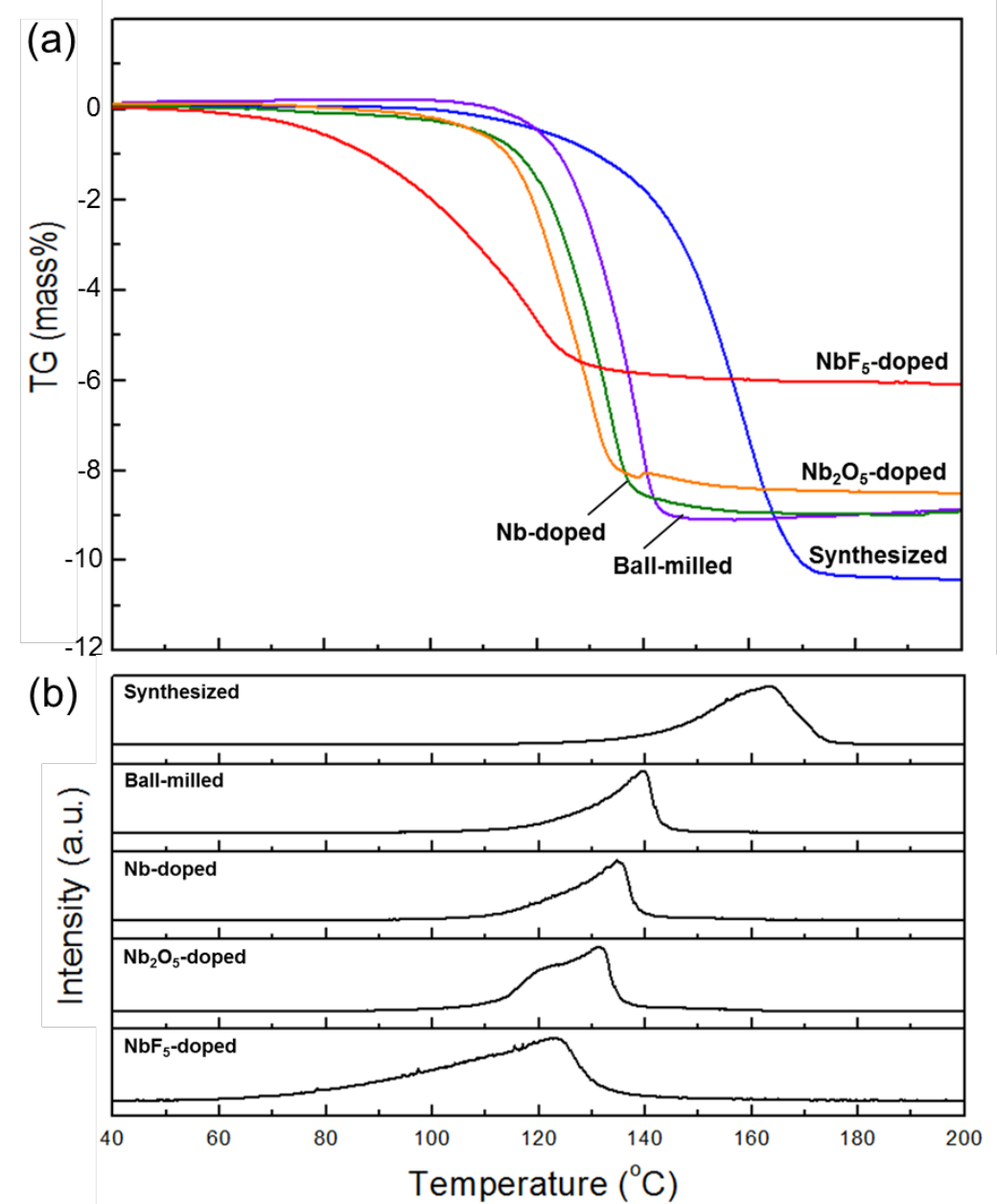

Fig. 1 (a) TG profiles and (b) MS ( $\left.\mathrm{m} / \mathrm{z}=2, \mathrm{H}_{2}\right)$ profiles of as-synthesized, ball-milled, and $\mathrm{Nb}-, \mathrm{Nb}_{2} \mathrm{O}_{5}-, \mathrm{NbF}_{5}$-doped $\mathrm{AlH}_{3}$. The amount of $\mathrm{Nb}$ species was $1 \mathrm{~mol} \%$ in each doped sample. The heating rate was $5{ }^{\circ} \mathrm{Cmin}^{-1}$. The mass loss value was calculated by using the total system mass.

lowest desorption temperature. It started to desorb hydrogen from $60{ }^{\circ} \mathrm{C}$ with a peak temperature at $122{ }^{\circ} \mathrm{C}$ (Fig.1(b)). However, the hydrogen mass loss of $\mathrm{NbF}_{5}$-doped $\mathrm{AlH}_{3}$ was only -6 mass $\%$, whose value was the smallest among all the samples. We also measured the sample with 5 mol\% $\mathrm{NbF}_{5}$ doping, but most of the hydrogen was released during ball-milling (The desorbed hydrogen amount during heating was only -1 mass\%.). Thus, doping a large amount of $\mathrm{NbF}_{5}$ promoted the decomposition during ball-milling. 


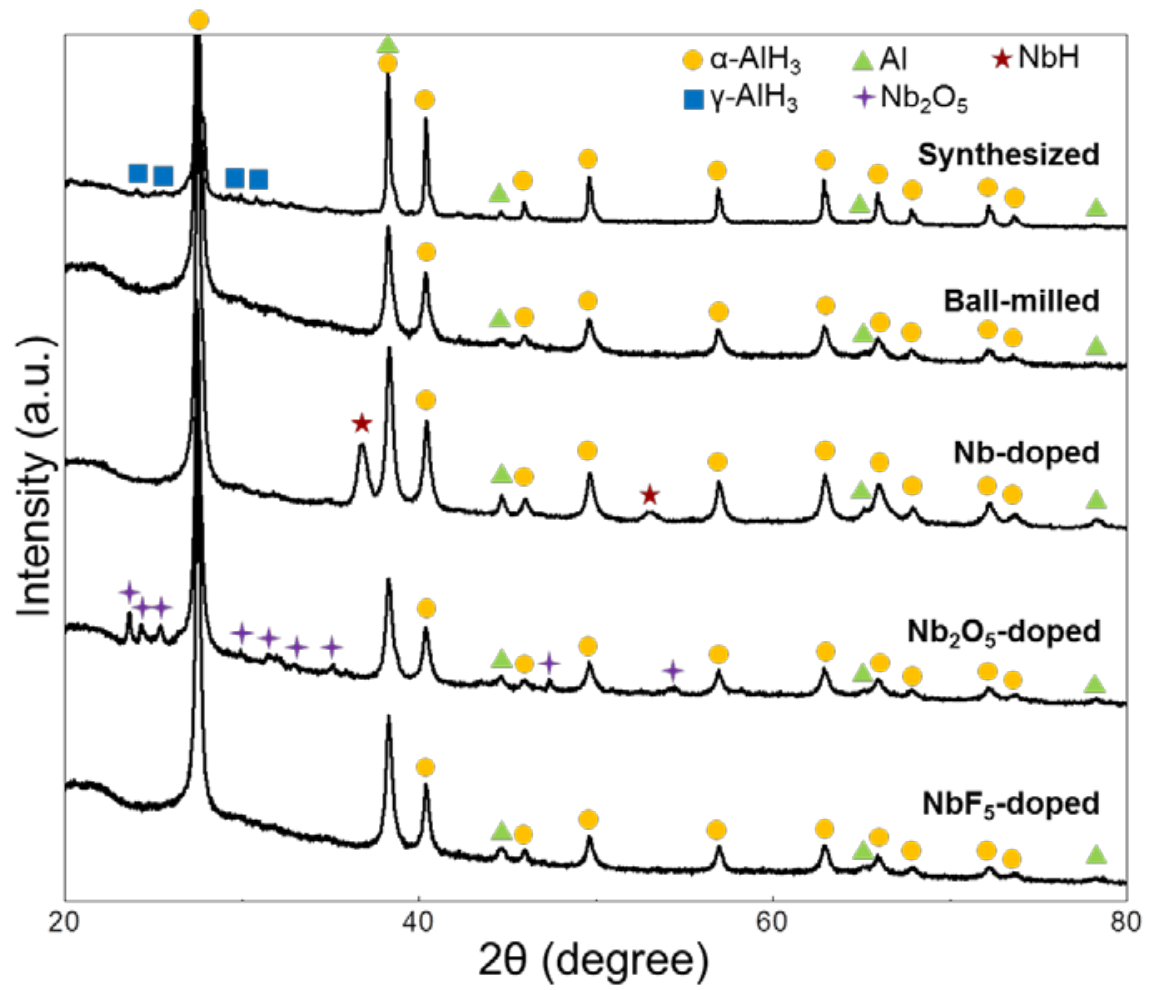

Fig. $2 \mathrm{XRD}$ patterns of as-synthesized, ball-milled, and $\mathrm{Nb}-, \mathrm{Nb}_{2} \mathrm{O}_{5}-, \mathrm{NbF}_{5}$-doped $\mathrm{AlH}_{3}$. The amount of $\mathrm{Nb}$ species was $1 \mathrm{~mol} \%$ in each doped sample.

Fig. 2 shows the XRD patterns of samples. Although as-synthesized sample contained $\alpha-\mathrm{AlH}_{3}$ and a small amount of $\gamma-\mathrm{AlH}_{3}$, ball-milled one did not contain $\gamma-\mathrm{AlH}_{3}$, probably due to its transformation to $\alpha-\mathrm{AlH}_{3}$ during milling [23]. The formation of $\mathrm{NbH}$ was observed in the $\mathrm{Nb}$ doped $\mathrm{AlH}_{3}$, indicating $\mathrm{Nb}$ reacted with $\mathrm{AlH}_{3}$ during ball-milling. In the $\mathrm{Nb}_{2} \mathrm{O}_{5}$-doped $\mathrm{AlH}_{3}$, $\mathrm{Nb}_{2} \mathrm{O}_{5}$ was observed after milling. In the case of $\mathrm{MgH}_{2}$ doped with $\mathrm{Nb}_{2} \mathrm{O}_{5}$, reduced $\mathrm{Nb}_{2} \mathrm{O}_{5-\mathrm{x}}$ phase was found on the surface of the samples [24]. Thus, the surface state of $\mathrm{Nb}_{2} \mathrm{O}_{5}$ could be also changed in the $\mathrm{Nb}_{2} \mathrm{O}_{5}$-doped $\mathrm{AlH}_{3}$ system. On the other hand, $\mathrm{Nb}$ - or F-containing phases were not observed in any of the diffraction patterns of the $\mathrm{NbF}_{5}$-doped $\mathrm{AlH}_{3}$. In order to investigate the distribution states of $\mathrm{Nb}$ dopants, SEM-EDS measurements were conducted for $\mathrm{NbF}_{5}$ - and $\mathrm{Nb}_{2} \mathrm{O}_{5}$-doped $\mathrm{AlH}_{3}$ (Fig. 3). As shown in Fig. 3(a), micron-particles containing $\mathrm{Nb}$ or F were not observed from the EDS mapping images. Similar results were obtained in the case of 
(a)

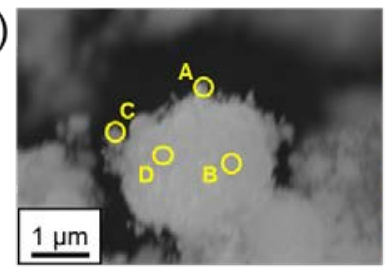

Results of Point Analysis

\begin{tabular}{|ccccc|}
\multicolumn{3}{r}{ Results of Point Analysis } & & (at. \%) \\
\hline & A & B & C & D \\
\hline Al & 63.2 & 67.8 & 66.2 & 60.2 \\
\hline O & 33.6 & 29.7 & 29.8 & 36.5 \\
\hline Nb & 0.8 & 0.7 & 1.2 & 0.7 \\
\hline F & 2.4 & 1.8 & 2.8 & 2.6 \\
\hline
\end{tabular}

(b)

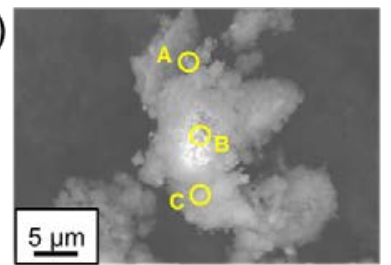

Results of PointAnalysis (at. \%)

\begin{tabular}{|cccc|}
\hline & A & B & C \\
\hline Al & 62.4 & 67.0 & 68.0 \\
\hline O & 36.1 & 32.3 & 31.3 \\
\hline $\mathrm{Nb}$ & 1.5 & 0.7 & 0.7 \\
\hline
\end{tabular}
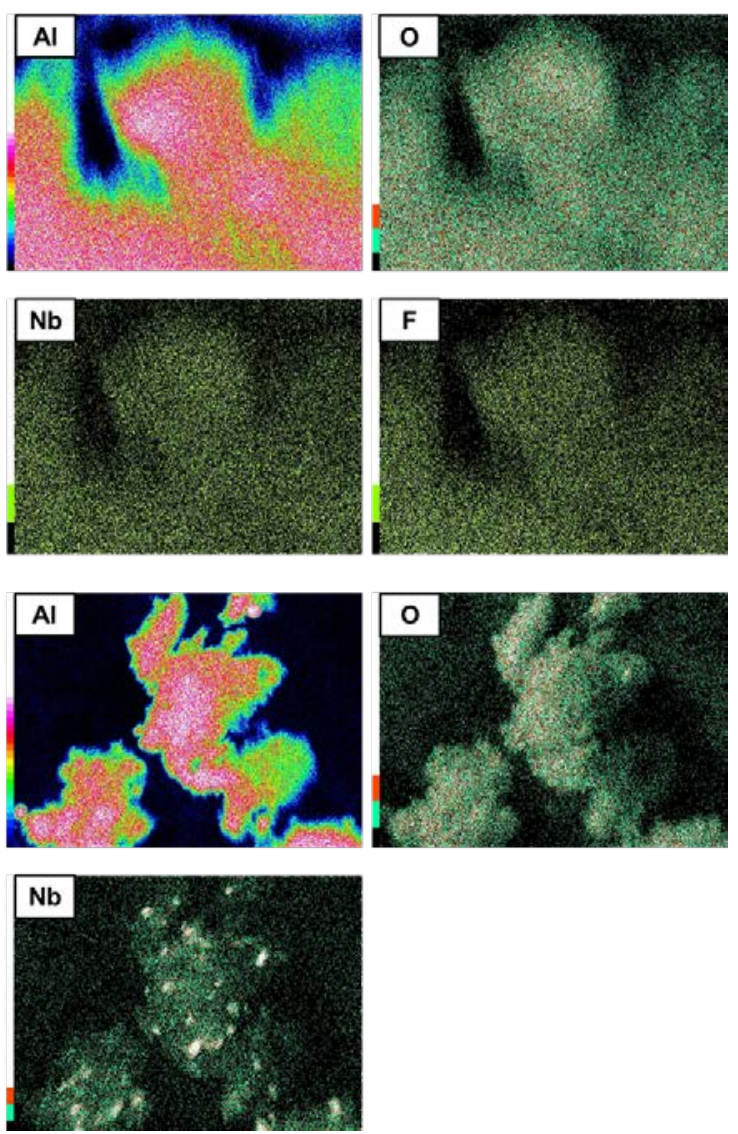

Fig. 3 SEM-EDS results of (a) 1 mol\% $\mathrm{NbF}_{5}$-doped $\mathrm{AlH}_{3}$ and (b) 1 mol\% $\mathrm{Nb}_{2} \mathrm{O}_{5}$-doped $\mathrm{AlH}_{3}$. Secondary-electron images and EDS results (point analysis and mapping images) are shown.

$5 \mathrm{~mol}^{\mathrm{N}} \mathrm{NbF}_{5}$ doping. On the other hand, the micron-particles containing $\mathrm{Nb}$ and $\mathrm{O}$ were clearly observed in the $\mathrm{Nb}_{2} \mathrm{O}_{5}$-doped $\mathrm{AlH}_{3}$. Thus, it seemed that $\mathrm{Nb}$ and $\mathrm{F}$ distributed uniformly on the surface of $\mathrm{AlH}_{3}$ in the $\mathrm{NbF}_{5}$-doped $\mathrm{AlH}_{3}$. The fine distribution of $\mathrm{Nb}$ and $\mathrm{F}$ was also observed in other $\mathrm{NbF}_{5}$-doped hydride systems $[8,25,26]$. For instance, Kim et al. suggested that $\mathrm{NbF}_{5}$ will melt during ball-milling and this promoted the presence of extremely fine $\mathrm{Nb} / \mathrm{NbH}$ film on the surface of $\mathrm{MgH}_{2}$ particles in $\mathrm{NbF}_{5}$-doped $\mathrm{MgH}_{2}$ system [25,26]. Thus, compared with $\mathrm{Nb}$ - or $\mathrm{Nb}_{2} \mathrm{O}_{5}$-doped $\mathrm{AlH}_{3}$, the fine distribution of dopant was successfully achieved in the $\mathrm{NbF}_{5}$-doped $\mathrm{AlH}_{3}$. 


\section{Investigation of $\mathrm{NbF}_{5}$-doped $\mathrm{AlH}_{3}$}

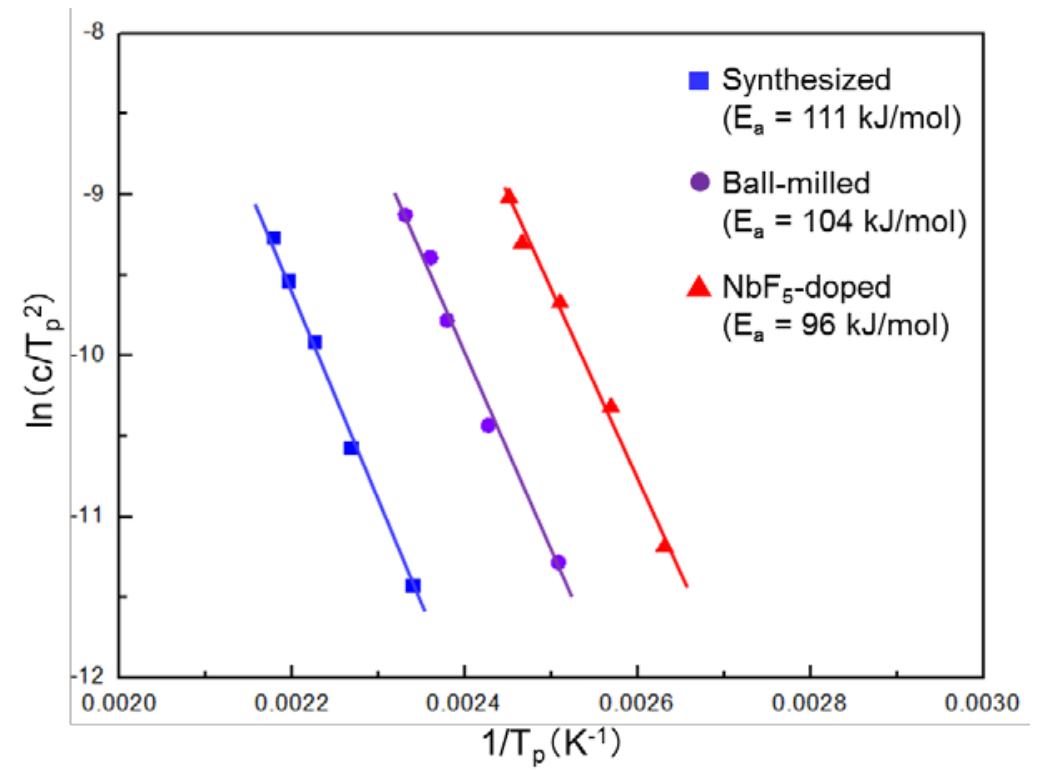

Fig. 4 Kissinger plots for hydrogen desorption of as-synthesized, ball-milled and $1 \mathrm{~mol} \%$ $\mathrm{NbF}_{5}$-doped $\mathrm{AlH}_{3}$.

In order to get an insight on the desorption mechanism, further investigation was conducted for the $\mathrm{NbF}_{5}$-doped $\mathrm{AlH}_{3}$, which showed the lowest onset temperature among all the samples. The activation energy for hydrogen desorption was analyzed for the $\mathrm{NbF}_{5}$-doped $\mathrm{AlH}_{3}$. Fig. 4 shows the Kissinger plots for the hydrogen desorption of $\mathrm{AlH}_{3}$ and $\mathrm{NbF}_{5}$-doped $\mathrm{AlH}_{3}$. The apparent activation energy for hydrogen desorption is calculated by using Kissinger equation [27],

$\ln \frac{c}{T_{p}^{2}}=-\frac{E_{a}}{R T_{p}}+\ln \frac{R A}{E_{a}}$

where $E_{a}$ is the apparent activation energy for hydrogen desorption, $c$ is the heating rate, $T_{p}$ is the peak temperature, $R$ is gas constant, and $A$ is the frequency factor. The activation energies of assynthesized $\mathrm{AlH}_{3}$, ball-milled $\mathrm{AlH}_{3}$, and $\mathrm{NbF}_{5}$-doped $\mathrm{AlH}_{3}$ were calculated to be 111,104 , and $96 \mathrm{~kJ} / \mathrm{mol}$, respectively. The values for as-synthesized and ball-milled $\mathrm{AlH}_{3}$ were similar to those 

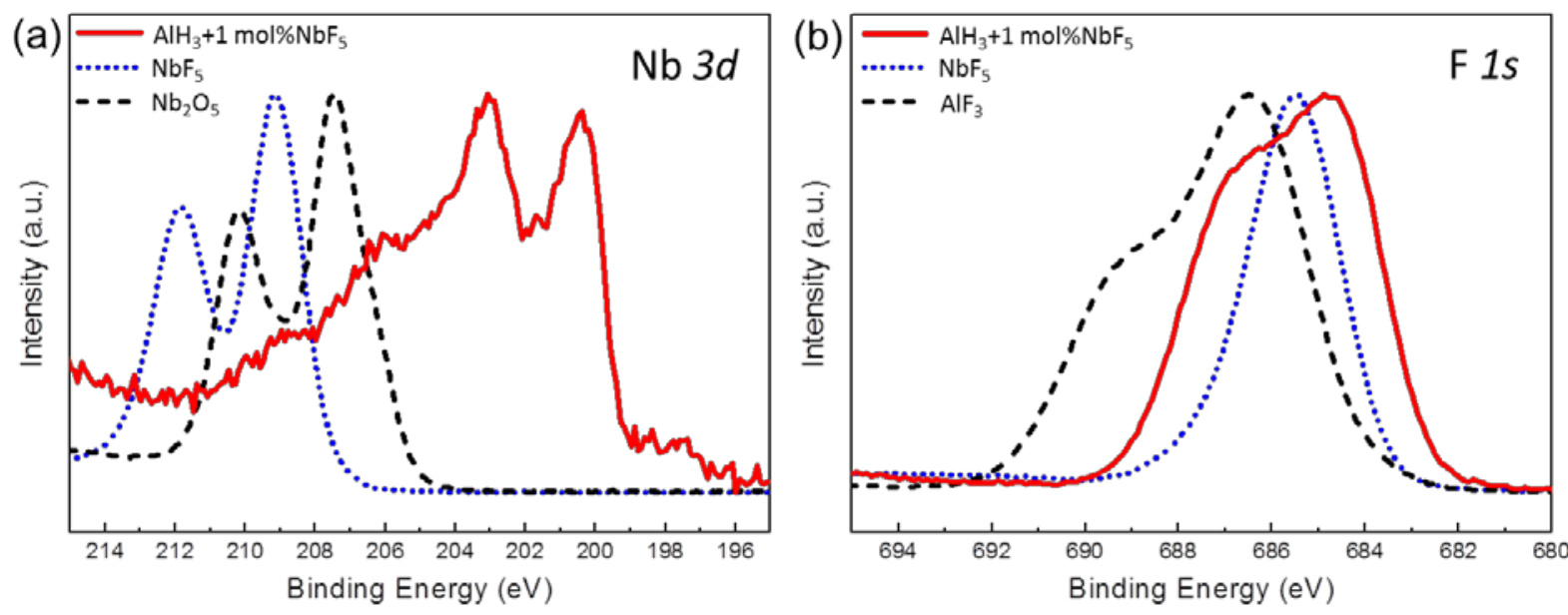

Fig. 5 XPS spectra of (a) $\mathrm{Nb} 3 d$ and (b) $\mathrm{F} 1$ s regions of 1 mol\% $\mathrm{NbF}_{5}$-doped $\mathrm{AlH}_{3}$. The spectra of $\mathrm{NbF}_{5}, \mathrm{Nb}_{2} \mathrm{O}_{5}$ and $\mathrm{AlF}_{3}$ are also shown as references.

of the previous study (104 kJ/mol [5], $102 \mathrm{~kJ} / \mathrm{mol}$ [28]). The activation energy of $\mathrm{NbF}_{5}$-doped $\mathrm{AlH}_{3}$ was just slightly decreased compared with as-synthesized and ball-milled $\mathrm{AlH}_{3}$. As shown in the "Introduction” part, $\mathrm{Ti}$ is known as an effective catalyst for $\mathrm{AlH}_{3}$. It was reported that a decrease of the activation energy by at least $50 \%$ is possible with the addition of $\mathrm{Ti}$ [6]. Thus, the effect of $\mathrm{Nb}$ on the decomposition kinetics would be less pronounced than that of Ti. The effect of cation species on the kinetics should be further clarified to understand the catalytic mechanism of hydrogen desorption from $\mathrm{AlH}_{3}$.

The bonding states of $\mathrm{Nb}$ and $\mathrm{F}$ elements were studied by using XPS. For comparison, the standard materials of $\mathrm{NbF}_{5}, \mathrm{Nb}_{2} \mathrm{O}_{5}$ and $\mathrm{AlF}_{3}$ were also measured. Fig. 5(a) shows the XPS spectra of $\mathrm{Nb} 3 d$ region. In the $\mathrm{NbF}_{5}$-doped $\mathrm{AlH}_{3}$, the binding energies of $\mathrm{Nb} 3 d_{3 / 2}$ and $3 d_{5 / 2}$ shift towards to the chemical states of $\mathrm{Nb}$, suggesting the reaction between $\mathrm{NbF}_{5}$ and $\mathrm{AlH}_{3}$ would occur to form Nb. Also, shoulder peaks appeared between 204.0-212.0 eV, suggesting the presence of $\mathrm{Nb}$ oxide species e.g., $\mathrm{Nb}_{2} \mathrm{O}_{5}$ and/or NbO. Fig. 5(b) shows the XPS spectra of $\mathrm{F} 1 \mathrm{~s}$ region. In the $\mathrm{NbF}_{5}$-doped $\mathrm{AlH}_{3}$, the binding energies of $\mathrm{F} 1$ s peaks were observed at $686.5 \mathrm{eV}$ 
$\left(\mathrm{AlF}_{3}\right)$ and a new peak at $684.8 \mathrm{eV}$. The new peak position is similar to the previously reported $\mathrm{AlF}_{\mathrm{x}} \mathrm{O}_{\mathrm{y}}$ species [29], suggesting such kind of $\mathrm{AlF}_{\mathrm{x}} \mathrm{O}_{\mathrm{y}}$ phase could exist. The broad peak at 688.9 $\mathrm{eV}$ in the starting material of $\mathrm{AlF}_{3}$ might be attributed to the contamination of C-F species [30]. The XPS results suggest that the following reaction would occur during the milling process: $10 \mathrm{AlH}_{3}+6 \mathrm{NbF}_{5} \rightarrow 10 \mathrm{AlF}_{3}+6 \mathrm{Nb}+15 \mathrm{H}_{2}$ whose Gibbs free energy $\Delta G^{\circ}=-3570.4 \mathrm{~kJ}$ [31,32] is possible from the thermodynamic potentials. The $\mathrm{Nb}$ spectrum in the $\mathrm{NbF}_{5}$-doped $\mathrm{AlH}_{3}$ (Fig.5 (a)) was similar to that of $\mathrm{NbF}_{5}$ doped $\mathrm{MgH}_{2}$ system [15]. In this system, $\mathrm{MgF}_{2}$ and $\mathrm{Nb}$ were formed by the reaction between $\mathrm{MgH}_{2}$ and $\mathrm{NbF}_{5}$. Thus, the chemical state of $\mathrm{Nb}$ was similar between $\mathrm{AlH}_{3}$ and $\mathrm{MgH}_{2}$ system. However, the existence of oxide species $\left(\mathrm{Nb}\right.$ oxide, $\mathrm{AlF}_{\mathrm{x}} \mathrm{O}_{\mathrm{y}}$ ) could be one of the characteristics in the $\mathrm{AlH}_{3}$ system. It is known that amorphous- or $\chi-\mathrm{Al}_{2} \mathrm{O}_{3}$ film exists on the surface of $\mathrm{AlH}_{3}$ particles [33,34]. Due to the lack of the standard Gibbs free energy of formation for amorphousor $\chi-\mathrm{Al}_{2} \mathrm{O}_{3}$, we considered the reaction with the most stable phase, $\alpha-\mathrm{Al}_{2} \mathrm{O}_{3}$, as follows:

$5 \mathrm{Al}_{2} \mathrm{O}_{3}+6 \mathrm{NbF}_{5} \rightarrow 3 \mathrm{Nb}_{2} \mathrm{O}_{5}+10 \mathrm{AlF}_{3}$

whose Gibbs free energy $\Delta G^{\circ}=-1442.2 \mathrm{~kJ}$ [31] is thermodynamically possible. Thus, $\mathrm{NbF}_{5}$ could also react with surface $\mathrm{Al}_{2} \mathrm{O}_{3}$ film in the $\mathrm{NbF}_{5}$-doped $\mathrm{AlH}_{3}$ system. In order to clarify the detailed catalytic mechanism, e.g., in-situ measurements on the reaction process between $\mathrm{NbF}_{5}$ and surface $\mathrm{Al}_{2} \mathrm{O}_{3}$ film should be conducted. As the summary of XPS results, the formation of finely dispersed $\mathrm{Nb}$ species and/or $\mathrm{AlF}_{3}$ could have the catalytic effect for hydrogen desorption of $\mathrm{AlH}_{3}$. According to the previous study, $\mathrm{AlF}_{3}$-doped $\mathrm{AlH}_{3}$ led to the decomposition of $\mathrm{AlH}_{3}$ at room temperature [35], suggesting $\mathrm{AlF}_{3}$ may have such catalytic effect. 


\section{Conclusion}

In summary, the addition of $\mathrm{Nb}$ species $\left(\mathrm{Nb}, \mathrm{Nb}_{2} \mathrm{O}_{5}, \mathrm{NbF}_{5}\right)$ enhanced the hydrogen desorption properties of $\alpha-\mathrm{AlH}_{3}$. In particular, $1 \mathrm{~mol} \% \mathrm{NbF}_{5}$-doped $\mathrm{AlH}_{3}$ started to desorb hydrogen from $60{ }^{\circ} \mathrm{C}$ with a peak temperature at $122{ }^{\circ} \mathrm{C}$. Compared with $\mathrm{Nb}$ - or $\mathrm{Nb}_{2} \mathrm{O}_{5}$-doped $\mathrm{AlH}_{3}$, the fine distribution of dopant was observed in the $\mathrm{NbF}_{5}$-doped $\mathrm{AlH}_{3}$. The activation energy for hydrogen desorption was slightly decreased by doping $\mathrm{NbF}_{5}$. From the XPS analysis, the reactions between $\mathrm{NbF}_{5}$ and $\mathrm{AlH}_{3}$ (surface $\mathrm{Al}_{2} \mathrm{O}_{3}$ film) were suggested. The improvement in the $\mathrm{NbF}_{5}$-doped $\mathrm{AlH}_{3}$ might be ascribed to the formation of finely distributed $\mathrm{Nb}$ and/or $\mathrm{AlF}_{3}$.

\section{AUTHOR INFORMATION}

\section{Corresponding Author}

* Corresponding author. Tel.: +81 11706 6769; Fax: +81 117066772.

E-mail addresses: y-nakagawa@eng.hokudai.ac.jp (Y. Nakagawa)

\section{Acknowledgements}

A part of this work was conducted at "Joint-Use Facilities: Laboratory of Nano-Micro Material Analysis" at Hokkaido University, supported by the "Material Analysis and Structure Analysis Open Unit (MASAOU)” and “Nanotechnology Platform” Program of the Ministry of Education, Culture, Sports, Science and Technology (MEXT), Japan.

\section{References}

[1] J. Graetz, ISRN Materials Science 2012 (2012) 863025. 
[2] J. Graetz, J. J. Reilly, J. G. Kulleck, R. C. Bowman, J. Alloys Comp. 446-447 (2007) 271275.

[3] G. Sandrock, J. Reilly, J. Graetz, W. M. Zhou, J. Johnson, J. Wegrzyn, J. Alloys Comp. 421 (2006) 185-189.

[4] Y. Nakagawa, S. Isobe, Y. Wang, N. Hashimoto, S. Ohnuki, L. Zeng, S. Liu, T. Ichikawa, Y. Kojima, J. Alloys Comp. 580 (2013) S163-S166.

[5] I. Gabis, M. Dobrotvorskiy, E. Evard, A. Voyt, J. Alloys Comp. 509S (2011) S671-S674.

[6] J. Graetz, J. J. Reilly, V. A. Yartys, J. P. Maehlen, B. M. Bulychev, V. E. Antonov, B. P. Tarasov, I. E. Gabis, J. Alloys Comp. 509S (2011) S517-S528.

[7] H. Liu, X. Wang, Y. Liu, Z. Dong, H. Ge, S. Li, M. Yan, J. Phys. Chem. C 118 (2014) 37-45.

[8] H. Liu, X. Wang, Y. Liu, Z. Dong, S. Li, H. Ge, M. Yan, J. Phys. Chem. C 118 (2014) 18908-18916.

[9] H. Liu, X. Wang, H. Zhou, S. Gao, H. Ge, S. Li, M. Yan, Int. J. Hydrogen Energy 41 (2016) 22118-22127.

[10] C. W. Duan, L. X. Hu, Y. Sun, H. P. Zhou, H. Yu, Phys. Chem. Chem. Phys. 17 (2015) 22152-22159.

[11] G. Barkhordarian, T. Klassen, R. Bormann, J. Alloys Comp. 364 (2004) 242-246.

[12] N. Hanada, T. Ichikawa, S. Hino, H. Fujii, J. Alloys Comp. 420 (2006) 46-49.

[13] T. Ma, S. Isobe, Y. Wang, N. Hashimoto, S. Ohnuki, J. Phys. Chem. C 117 (2013) 1030210307.

[14] T. Kimura, H. Miyaoka, T. Ichikawa, Y. Kojima, Int. J. Hydrogen Energy 38 (2013) 1372813733.

[15] Y. Luo, P. Wang, L. P. Ma, H. M. Cheng, J. Alloys Comp. 453 (2008) 138-142. 
[16] N. Recham, V. V. Bhat, M. Kandavel, L. Aymard, J. M. Tarascon, A. Rougier, J. Alloys Comp. 464 (2008) 377-382.

[17] M. Ismail, Y. Zhao, X. B. Yu, S. X. Dou, Int. J. Hydrogen Energy 35 (2010) 2361-2367.

[18] J. Mao, Z. Guo, H. Liu, Int. J. Hydrogen Energy 36 (2011) 14503-14511.

[19] H. Kou, G. Sang, Y. Zhou, X. Wang, Z. Huang, W. Luo, L. Chen, X. Xiao, G. Yang, C. Hu, Int. J. Hydrogen Energy 39 (2014) 11675-11682.

[20] H. J. Lin, J. Matsuda, H. W. Li, M. Zhu, E. Akiba, J. Alloys Comp. 645 (2015) S392-S396.

[21] M. Jangir, A. Jain, S. Yamaguchi, T. Ichikawa, C. Lal, I. P. Jain, Int. J. Hydrogen Energy 41 (2016) 14178-14183.

[22] F. M. Brower, N. E. Matzek, P. F. Reigler, H. W. Rinn, C. B. Roverts, D. L. Schmidt, J. A. Snover, K. Terada, J. Am. Chem. Soc. 98 (1976) 2450-2453.

[23] S. Orimo, Y. Nakamori, T. Kato, C. Brown, C. M. Jensen, Appl. Phys. A 83 (2006) 5-8.

[24] T. Ma, S. Isobe, E. Morita, Y. Wang, N. Hashimoto, S. Ohnuki, T. Kimura, T. Ichikawa, Y. Kojima, Int. J. Hydrogen Energy 36 (2011) 12319-12323.

[25] J. W. Kim, J. P. Ahn, S. A. Jin, S. H. Lee, H. S. Chung, J. H. Shim, Y. W. Cho, K. H. Oh, J. Power Sources 178 (2008) 373-378.

[26] J. W. Kim, J. P. Ahn, D. H. Kim, H. S. Chung, J. H. Shim, Y. W. Cho, K. H. Oh, Scr. Mater. $62(2010)$ 701-704.

[27] H. E. Kissinger, Anal. Chem. 29 (1957) 1702-1706.

[28] J. Graetz, J. J. Reilly, J. Phys. Chem. B 109 (2005) 22181-22185.

[29] X. Wu, P. Cong, S. Mori, Appl. Surf. Sci. 201 (2002) 115-122.

[30] A. Limcharoen, C. Pakpum, P. Limsuwan, Procedia Engineering 32 (2012) 1043-1049. 
[31] D. D. Wagman, W. H. Evans, V. B. Parker, R. H. Schumm, I. Halow, S. M. Bailey, K. L. Churney, R. L. Nuttall, J. Phys. Chem. Ref. Data 11 (1982) Suppl. 2.

[32] J. Graetz, J. Reilly, G. Sandrock, J. Johnson, W. M. Zhou, J. Wegrzyn, Brookhaven National Laboratory Formal Report BNL-77336-2006 (2006).

[33] S. Muto, K. Tatsumi, K. Ikeda, S. Orimo, J. Appl. Phys. 105 (2009) 123514.

[34] K. Ikeda, H. Ohshita, N. Kaneko, J. Zhang, M. Yonemura, T. Otomo, K. Suzuya, H. Yukawa, M. Morinaga, H. W. Li, S. Semboshi, S. Orimo, Mater. Trans. 52 (2011) 598-601.

[35] J. E. Fonneløp, M. Corno, H. Grove, E. Pinatel, M. H. Sørby, P. Ugliengo, M. Baricco, B. C. Hauback, J. Alloys Comp. 509 (2011) 10-14. 